\title{
Treatment With Cholecalciferol Leads to Increase Of Selected Semen Parameters in Young Infertile Males: Results of a 6-month Interventional Study
}

\author{
Igor BARTL ${ }^{1,2}$, Miroslava ONDRUŠOVÁ ${ }^{1}$, Martin KUŽMA ${ }^{1}$, Peter JACKULIAK ${ }^{1}$, Andrea \\ GAŽOVÁ ${ }^{3}$, Ján KYSELOVIČ ${ }^{1}$, Juraj PAYER ${ }^{1}$
}

${ }^{1} 5^{\text {th }}$ department of Internal Medicine Comenius University Faculty of Medicine, University Hospital Bratislava, Slovakia, ${ }^{2}$ Urological and Sexological Clinical Outpatient Clinic, Department of Urology, Ružinov Hospital, University Hospital Bratislava, Slovakia, ${ }^{3}$ Institute of Pharmacology and Clinical Pharmacology, Faculty of Medicine, Comenius University Bratislava, Slovakia

Received June 8, 2021

Accepted September 10, 2021

\begin{abstract}
Summary
High incidence of infertility along with low vitamin D levels was detected in otherwise healthy young men. The aim is to observe the effect of vitamin D supplementation on semen parameters as assessed by semen analysis in infertile men. In total, 45 men (mean age 36.6 years) in consecutive order were included, of whom 34 finished the study. Subjects were supplemented by vitamin D (cholecalciferol) 2500 IU/day. Vitamin D levels were assessed by HPLC. Semen analysis was performed strictly following $2010 \mathrm{WHO}$ guidelines. Study periods were baseline and month 6. During follow-up, $20 \%, 7.4 \%, 22 \%$ and $0.7 \%$ increase in serum vitamin $\mathrm{D}$ levels, progressive sperm motility, sperm concentration and sperm morphology, respectively, were observed (all $\mathrm{p}$ <0.05). At follow-up end, 9 patients $(26 \%)$ reached normal sperm parameters of whom 2 fertilized their partner. There was no correlation between vitamin $D$ and semen parameters observed. This study proves that vitamin D supplementation is possibly a modulator of sperm parameters in vitamin $D$ deficient, otherwise healthy men. Although a direct relationship between vitamin $D$ and sperm parameters was not observed obtaining adequate vitamin $\mathrm{D}$ levels could likely play a role in the male factor of infertility.
\end{abstract}

\section{Key words}

Vitamin D • Vitamin D receptor • Infertility • Male health

\section{Corresponding author}

Igor Bartl, Urological and sexological clinical outpatient clinic, Department of Urology, University Hospital Bratislava, Ružinovská 6, 82601 Bratislava, Slovakia. Email: SSS.igorbart|@gmail.com

\section{Introduction}

Currently, male infertility exceeds the fertilization process and multidisciplinary aspects of disrupted male fertility were proposed. A connection between young infertile men and a higher incidence of cardiovascular disease or higher risk of diabetes and hyperlipidemia was observed (Glazer et al. 2017, Kasman et al. 2019, Rastrelli et al. 2019). In otherwise healthy men and women, a high prevalence of infertility together with low vitamin D levels is present (Cito et al. 2020). Thus, associations between vitamin D and male fertility, as represented by sperm count, could thus be a suitable target for future research of infertility treatment options (Alzoubi et al. 2017). The chemical structure of native vitamin D corresponds to steroid hormones and also acts through the nuclear receptor, named vitamin $\mathrm{D}$ receptor (VDR). In kidneys, 25-(OH)-D is metabolized by 1 - $\alpha$-hydroxylase (CYP27B1) in an active form of 1.25-dihydroxyvitamin D. Vitamin D, similarly, as total testosterone (TT), can modulate genomic and nongenomic processes. Thus, significant differences and variability of regulatory domains within a few days to minutes or seconds can be observed (Bouillon et al. 2019).

Cumulative evidence from human and nonhuman studies suggests, that vitamin D has an important role not only in musculoskeletal tissue health and

PHYSIOLOGICAL RESEARCH • ISSN 1802-9973 (online) - an open access article under the CC BY-NC-ND 4.0 license (c) 2021 Institute of Physiology of the Czech Academy of Sciences, Prague, Czech Republic Fax +420 241062 164, e-mail: physres@fgu.cas.cz, www.biomed.cas.cz/physiolres 
metabolism but also in reproduction associated regulatory mechanisms in both sexes. Basics of interaction between vitamin $\mathrm{D}$ and reproduction origins in the presence of VDR and 1 $\alpha$-hydroxylase (CYP27B1) enzyme in reproductive organs (Jueraitetibaike et al. 2019). More recently, the extraskeletal effects of vitamin $\mathrm{D}$ and the understanding of the molecular mechanisms of biologically active vitamin $\mathrm{D}$ metabolite calcitriol revealed other possibilities that deterioration of VDR sensitivity in the target organs could play a key role in the vitamin D effect on human fertility (Macova et al. 2018).

In the study by Bøllehuus Hansen et al. the VDR expression was decreased in infertile males in comparison to healthy controls (Bøllehuus Hansen et al. 2017). It supports the hypothesis, that the metabolizing and reacting capability to the active form of vitamin $\mathrm{D}$ is different, somehow less functional, compared to healthy men. It has been suggested that vitamin D plays important role in cell cycle regulation and malignant germinal cells differentiation (Blomberg et al. 2012, Jorgensen et al. 2011), but the exact function of vitamin $\mathrm{D}$ in spermatogenesis regulation remains unclear. According to the latest recommendations, vitamin D deficiency is considered to be below $20 \mathrm{ng} / \mathrm{ml}$ of serum vitamin D level. In recent years, a new term insufficiency of vitamin D was established, which characterizes the state of reduced levels of 25-(OH)-D (less than $30 \mathrm{ng} / \mathrm{ml}$ thus 21-29 ng/ml) (Jackuliak et al. 2012). Although some environmental studies suggest that the target level should be fixed much higher than $100-120 \mathrm{ng} / \mathrm{ml}$ (Pludowsku et al. 2013) the optimal vitamin D concentration has been established between 20 and $50 \mathrm{ng} / \mathrm{ml}$ (Rosen et al. 2012).

In this study, the effect of vitamin D supplementation on semen parameters was assessed by sperm analysis in infertile men.

\section{Patients and methods}

A prospective, single-centre study in male outpatients 5/2019-12/2020 was conducted. All study procedures were reviewed and approved by the local ethics committee (approval number 091/2019). Each patient before any study procedure signed informed consent.

Inclusion criteria were as follows:

- Men from permanent spouses/couples who, after one year of regular unprotected sexual intercourse, have failed to reach the pregnancy of their wives/partners aged $\geq 18$ years,

- male infertility confirmed by a certified institution with $2 \mathrm{x}$ repeated analysis of semen with sperm concentration $\geq 1$ million $/ \mathrm{ml}$.

- all men must have confirmed findings in a standard semen analysis: either $<15 \mathrm{million} / \mathrm{ml}$ spermatozoa, or $<32 \%$ progressive motile spermatozoa, or $<4 \%$ morphological normal spermatozoa, consistent with OAT (oligoasthenoteratozoospermia) findings.

Exclusion criteria were as follows:

- couples who reported infertility due to female factors,

- those on vitamin D therapy, receiving testosterone or thyroxin replacement therapy and calcium supplementation,

- those suffering from diabetes, parathyroid gland disease, hypertension, malabsorption, gastric bypass, celiac disease, inflammatory bowel disease and cancer,

- $\quad$ if there is an indication of a testicular biopsy and it is planned or performed within the next 6 months.

- A man was willing to change his usual personal habits, BMI, such as physical activity, smoking, alcohol consumption, etc.

- All subjects were supplemented with $2500 \mathrm{IU} /$ day of cholecalciferol for 6 months. During follow-up, 3 visits in each subject were performed.

Table 1. The normal values of semen analysis.

\begin{tabular}{ll}
\hline Parameter & $\begin{array}{c}\text { Lower limit } \\
\text { (range) }\end{array}$ \\
\hline Sperm volume (ml) & $1.5(1.4-1.7)$ \\
Total sperm count (million/ejaculate) & $39(33-46)$ \\
Sperm concentration (million/ml) & $15(12-16)$ \\
Total sperm motility (PR NP) & $40(38-42)$ \\
Progresive sperm motility $(P R, \%)$ & $32(31-34)$ \\
Vitality (viable sperm,\%) & $58(55-63)$ \\
Sperm morphology (normal forms, \%) & $4(3.0-4.0)$ \\
\hline
\end{tabular}

Semen analysis

Semen analysis was performed strictly following the 2010 WHO guidelines (Salonia et al. 2020). Semen 
samples were collected by masturbation after three to four days of abstinence. Samples were collected in sterile culture vials and left to liquefy for 20-30 minutes at room temperature. After liquefaction, the samples were analysed for physical and morphological parameters such as volume, liquefaction time, sperm count (million/ml), motility, and morphology (\%). (Table 1). Sperm motility was classified as progressive, non-progressive, and immotile. The process of semen analysis was done in a certified Center of reproductive medicine GYN-FIV a.s.

\section{Blood sample collection}

Venous blood $(2-3 \mathrm{ml})$ from the antecubital vein was collected in the morning ( 7 to 8 AM) from the patients. The serum was obtained by centrifugation and was stored at $-70{ }^{\circ} \mathrm{C}$ until further analysis in certified University Hospital Lab Bratislava.

\section{Evaluation of hormone profile}

Serum follicle-stimulating hormone (FSH), luteinizing hormone (LH), estradiol, prolactin (PRL), total testosterone (TT), free testosterone (fT) were estimated in patients by a two-step immunoassay using competitive immunoassay using chemiluminescent microparticle immunoassay (CMIA) technology with flexible assay protocols. Vitamin D levels were evaluated by measuring 25-(OH)-D in the serum by highperformance liquid chromatography (HPLC).

\section{Statistical analysis}

Data analysis was performed using the SAS Enterprise Guide program. We used regress and correlation analysis to scan dependency between examined variables. The continuous and categorical variables were presented as mean \pm standard deviation (SD) or median (minimum, maximum) and $\mathrm{n}(\%)$, respectively. Results were considered to be statistically significant if the p-value was less than 0.05 . We determined the significance of the model as a whole based on the result of the F-test.

\section{Results}

\section{Study group}

In total, 45 men (mean age 36.6 years) in consecutive order were included in the study according to inclusion criteria. From this number, only 34 men finished the study, 11 subjects did not continue due to the COVID-19 pandemic, no interest in continuing and unknown reasons decided not to finish the study. All men came from long-lasting partnerships (47\%) or marriages $(53 \%)$ with the duration of infertility ranged from 1 to 7 years, an average of 2.28 years. All baseline characteristics are in Table 2.

\section{Vitamin D levels}

At baseline, the mean serum vitamin D concentration in the study group was $24.40 \mathrm{ng} / \mathrm{ml}$, which is referred to as vitamin $\mathrm{D}$ insufficiency. The values ranged between $7.84 \mathrm{ng} / \mathrm{ml}$ and $42.60 \mathrm{ng} / \mathrm{ml}$. Vitamin D values in patients at the end of the research have reached $30.68 \mathrm{ng} / \mathrm{ml}$ on average (mean increase of $6.28 \mathrm{ng} / \mathrm{ml}$ ), 16 patients achieved normal levels of vitamin $\mathrm{D}$. In comparison to baseline values the number of patients suffering from vitamin D deficiency (10 patients) at the end of follow-up decreased from $70.5 \%$ to $50 \%$ (Fig. 1).

\section{Progressive sperm motility}

At baseline, the values of progressive sperm motility ranged from $0 \%$ to $80 \%$, with an average of $22-21 \%$, which is consistent with decreased sperm motility (reference range $31 \%-34 \%$ ). After 6-month vitamin D supplementation average sperm motility in the study group increased by $29.65 \%$, consistent with $+7.44 \%$ increase $(\mathrm{p}<0.05)$. In total, $12(26.74 \%)$ of patients achieved normal progressive sperm motility in comparison to baseline, when only $3(9 \%)$ patients matched the referential values as shown in Figure $2 \mathrm{a}$.

\section{Sperm concentration}

Baseline sperm concentration values ranged from $1.30 \mathrm{million} / \mathrm{ml}$ to $102 \mathrm{million} / \mathrm{ml}$ with mean of $15.31 \mathrm{million} / \mathrm{ml}$. In total, $8(25 \%)$ of patients matched the reference range (12-16 million/ml). After vitamin D supplementation, sperm concentration increased of $4.4 \mathrm{million} / \mathrm{ml}$ (approx. $+22 \%, \mathrm{p}<0.001$ ), ranged from $2.00 \mathrm{million} / \mathrm{ml}$ to $100 \mathrm{million} / \mathrm{ml} .24(75 \%)$ patients achieved the referential values, and 13 (40\%) of them achieved higher than normal values (more than 16 million $/ \mathrm{ml}$ ). In comparison to the beginning, the number of patients with referential values of sperm concentration increased from $25 \%$ to $75 \%$ (Fig. 2b).

At baseline, sperm morphology ranged from $0 \%$ to $10 \%$, with an average of $2.61 \% \pm \mathrm{SD}$. Reference value in average was not matched (3-4\%). After vitamin D supplementation, sperm morphology increased by $0.71 \%$ with an average value of $3.32 \%(\mathrm{p}<0.008)$. In total, $16(50 \%)$ of patients reached the reference value $(>4 \%)$, (Fig. 2c). 
Table 2. Comparison of observed parameters at baseline and at the end of follow-up

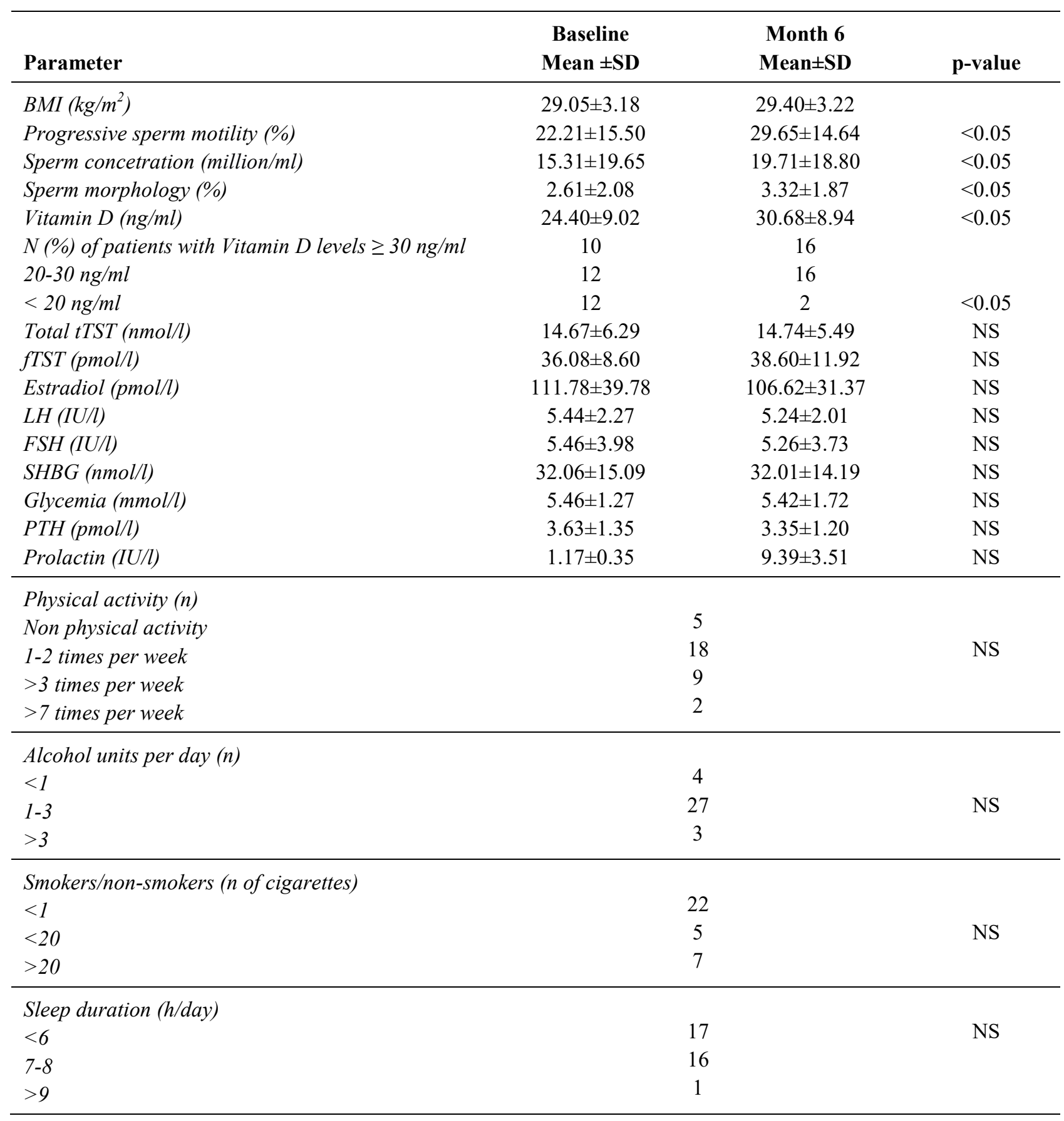

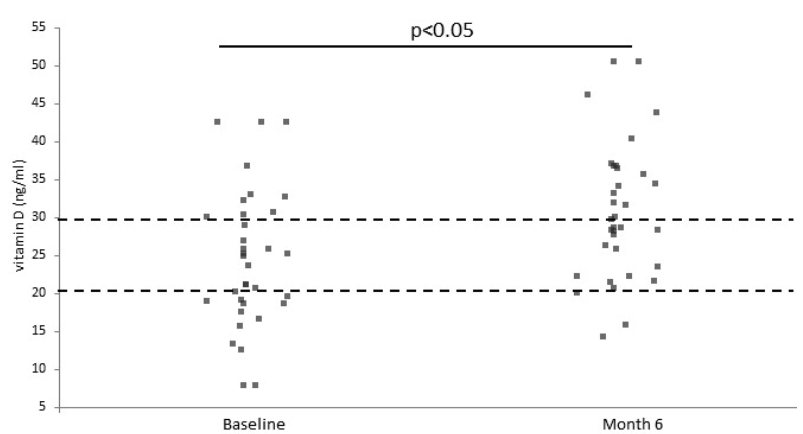

Fig. 1. Change of vitamin $D$ levels during follow-up

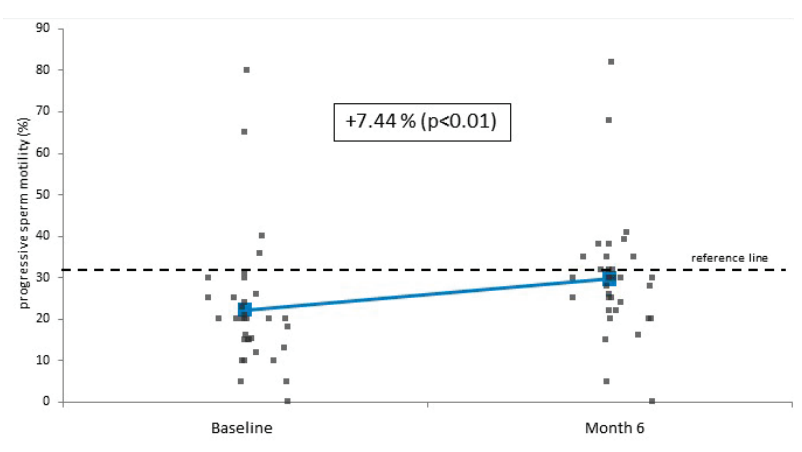

Fig. 2a. Effect of vitamin D supplementation on progressive sperm motility 


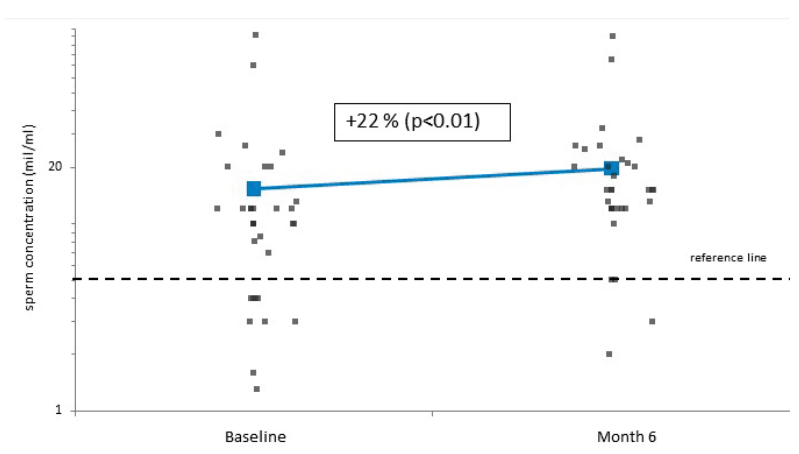

Fig. 2b. Effect of vitamin D supplementation on sperm concentration

\section{Sperm morphology}

Of the total number 34 patients, during follow up 9 patients $(26 \%)$ reached normal sperm parameters based on WHO recommendations (15). The results of 1 patient $(2.94 \%)$ changed from OAT (oligoasthenozoospermia i.e., low count, motility and low normal sperm morphology) to oligozoospermia and 23 patients (68\%) remained unchanged.

Correlation analysis did not show a significant

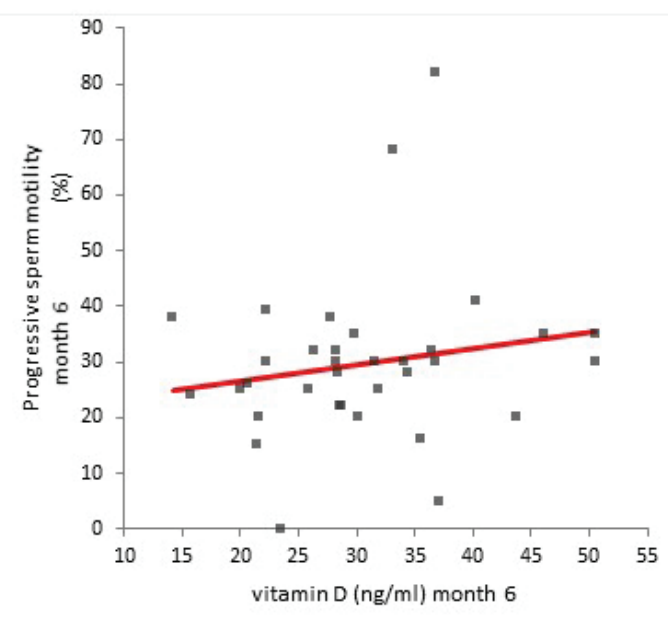

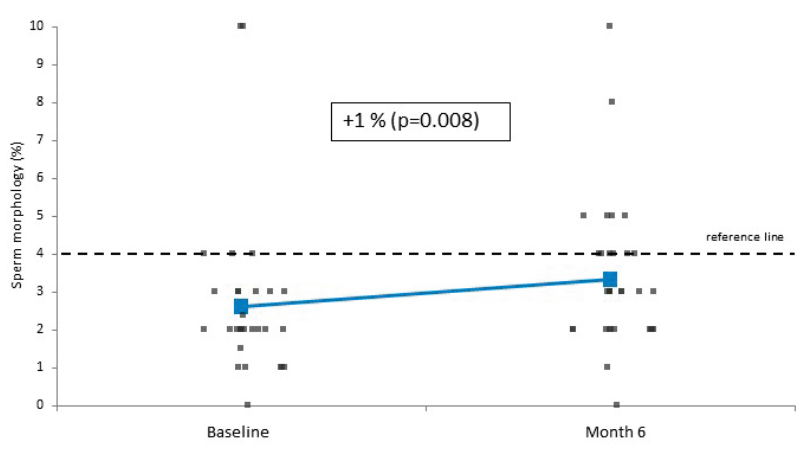

Fig. 2c. Effect of vitamin D supplementation on sperm concentration

association between vitamin $\mathrm{D}$ and selected sperm parameters, but a positive trend was between vitamin D levels and progressive motility and sperm concentration at month 6 was observed (Fig. 3). No association between testosterone levels and sperm parameters was observed.

After 6-months of vitamin D supplementation 2 cases of pregnancy were reported. Those two males had significantly improved semen parameters, reaching normal values for each parameter.

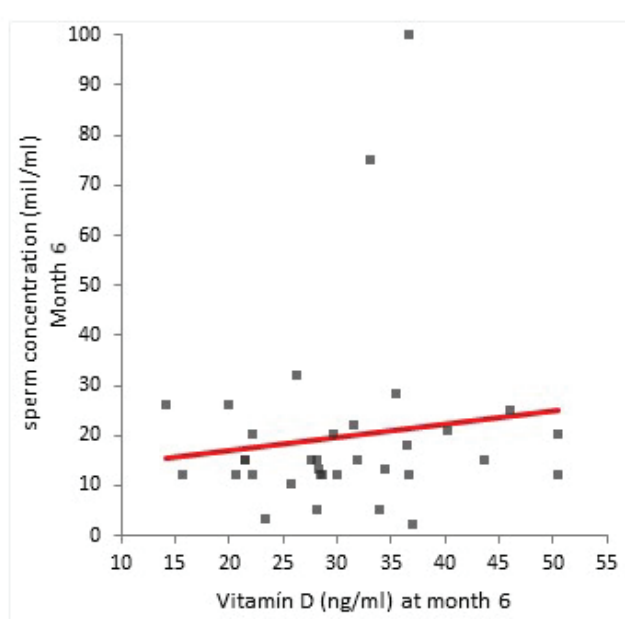

Fig. 3. Correlation analysis between levels of vitamin $D$ and sperm parameters at month 6 of the follow-up.

\section{Discussion}

In recent years, vitamin $\mathrm{D}$ due to its pleiotropic effects was discussed as the potential agent of benefit in the improvement of male fertility. In this study, we found that the vitamin D supplementation had positive semen parameters and observed a high sperm count in subjects with sufficient levels of 25-(OH)-D. This finding is consistent with recent studies (Ciccone et al. 2021, Rehman et al. 2018, Kumari et al. 2021), but in comparison with clinical studies (Blomberg et al. 2011, Blomberg et al. 2016, Ramlau-Hansen et al. 2011, Abbasihornozi et al. 2017, Hammoud et al. 2012, Cito et al. 2020). The international studies aimed to compare the serum level of vitamin D, TT, ionized calcium and phosphorus with sperm quality. The minority of the studies included lifestyle habits and BMI measuring. The studies used different dosage regimens of vitamin D for example initial single dose, other studies used continual dosing of vitamin D during the whole study. 
In a Danish study Bloomberg (2016), 300 men were observed, all of them were given an initial dose of $300000 \mathrm{IU}(7500 \mu \mathrm{g})$ per oral cholecalciferol (Blomberg et al. 2016). After DXA, a continuous daily dosage regimen was established, peroral supplementing $1400 \mathrm{IU}$ $(35 \mu \mathrm{g})$ of cholecalciferol with $500 \mathrm{mg}$ of calcium lasting 5 months (150 days). The age composition was very similar differing from 18 to 60 years, our study did not define the upper age limit. Potential differences in results may be caused by different age composition, body weight index, initial vitamin D serum levels and different study methodologies. Some of the studies were comparing two arms, one with pathological sperm analysis, the second with normozoospermic male pro-bands. Inclusion and exclusion criteria were similar in our study. Some of the studies extended the implementation of results into assisted reproduction cycles. Despite no clear explanation of vitamin D effect on male fertility, international studies, as well as our lead to a congruent result, that vitamin D supplementation is a simple, low cost, strongly biological modality of male infertility treatment.

Hammoud et al. (2012) observed (in 170 men) that low 25-(OH)-D levels were associated with decreased total sperm count and progressively motile sperm count but did not affect sperm concentration, progressive motility and normal morphology (Hammound et al. 2012). Literature indicates that $25-(\mathrm{OH})-\mathrm{D}$ raises intracellular calcium levels and motility of sperm, it also brings the acrosome reaction in mature spermatozoa, and there was a positive association between serum 25-(OH)-D levels and sperm motility (Blomberg, et al. 2011). Based on which it can be suggested that deficiency, as well as insufficiency, disturb sperm motility.

However, this study, in addition to significant improvement of sperm motility parameters described by listed studies, showed also an effect on sperm morphology and concentration. The observed differences in several studies may be due to heterogeneity in study design, methodology used, patient type, age group, and different cut-off values considered categorizing patients as vitamin $\mathrm{D}$ deficient. The eligible timing of vitamin $\mathrm{D}$ supplementation in case of male infertility, total daily dose, dosage form as well as duration of treatment remains still unclear. In addition to taking into account the personalized vitamin D response index (RamlauHansen et al. 2011) future examination of VDR and AR polymorphisms and further study of their multimodal effects (connectivity and variability of effects) could lead to more accurate vitamin D titration and identification of individual treatment acceptance.

In infertile males with severe oligoasthenoteratozoospermia along with deficient 25-(OH)-D levels, pregnancy outcomes are compromised if serum concentration should fall below $50 \mathrm{nmol} / \mathrm{l}$. In our study, we observed that increased total count, motility and normal morphology was significantly high in the group of male subjects who had sufficient 25-(OH)-D levels.

It is reported in the literature that the quality and count of sperms are dependent on many parameters such as the optimal level of enzymes, hormones, and antioxidants. 25-(OH)-D level may not affect sperm production directly but can be a major contributing factor when fertility is concerned. Here is inconsistency in the literature regarding the role of vitamin $\mathrm{D}$ in the production of sex hormones. A few studies have shown a positive correlation of serum vitamin $\mathrm{D}$ levels with total TT (Wehr et al. 2010). Another study reported a weak relationship of vitamin D levels with sex hormones in men (Wulaningsih et al. 2014). Several other studies have found no association of serum vitamin D levels with sex hormones in men (Anic et al. 2016). This was not confirmed by this study. However, there is a trend to the positive association between vitamin $\mathrm{D}$ and semen parameters e.g., sperm motility and concentration. However, the results were affected by sample size.

Blomberg et al. (2011) (observing 300 men) reported that serum calcium is imperative for spermatogenesis, sperm motility, and the acrosome reaction and 25-(OH)-D is a key regulator of the calcium and phosphate homeostasis (Blomberg et al. 2011). It may be hypothesized that 25-(OH)-D has a dual role in human reproduction and exert its function by maintaining calcium and phosphate homeostasis and by influencing sex hormone synthesis.

Ramlau-Hansen et al. (2011) found (observing 278 men) lower crude median total sperm count and percentage of normal morphology sperm with higher vitamin D (Ramlau-Hansen et al. 2011). This relation was attenuated and became not significant after correction for confounding factors. For their study, $94 \mathrm{nmol} / \mathrm{l}$ was used as the cut-off value for 'high vitamin D', which corresponds to $37.7 \mathrm{ng} / \mathrm{ml}$ Similar to our findings, Ramlau-Hansen et al. did not find the correlation between serum vitamin $\mathrm{D}$ and hormonal parameters. Our study and the study by RamlauHansen et al. demonstrated that a possible male reproductive toxicity or no benefit associated with serum 
vitamin $\mathrm{D}$ is observed at much lower levels than previously thought. These results are in parallel to studies reporting increased overall mortality in association with serum vitamin D levels occurring at levels of $75-120 \mathrm{nmol} / \mathrm{l}(30-50 \mathrm{ng} / \mathrm{ml})$.

After 6-months of vitamin D supplementation therapy, two males reported the pregnancy of their spouses. In both cases, vitamin D supplementation led to significant improvement of all three semen analysis parameters, in the following manner: motility, concentration and morphology, proving the thus positive effect of vitamin D supplementation.

This study has few limitations, such as sample size and the absence of a placebo group to compare outcomes of this study. However, the study has also several strengths, such as prospective interventional design, an adequate dose of vitamin $\mathrm{D}$, reflecting extraskeletal effects with daily administration. In addition, vitamin $\mathrm{D}$ has been evaluated with HPLC, which is considered the gold standard for the measurement of vitamin D concentration. The study group was well defined and the sex hormones and personal habits of the subjects were evaluated.

Such results show the clinical importance of vitamin D supplements in vitamin D-deficient infertile male subjects. However, the discrepancy in clinical data demands further longitudinal experimental studies on a larger scale with a large sample size to explore the precise role of 25-(OH)-D in male infertility.

To conclude, this study shows that supplementation of vitamin D is possibly beneficial for mobility, concentration and morphology sperm for male infertility. Further studies are required to elucidate the pathophysiology of this relation, its modulation by obesity in men and its relation to the overall male fertility. Examination of vitamin D levels in young men can be a significant step in the prevention and improvement of reproduction potential. Looking for correlations between variables of different categories could lead us to find more male health markers. Stratification of young male risk groups with the male factor of infertility is very important (Hanson et al. 2018).

\section{Conflict of Interest}

There is no conflict of interest.

\section{Acknowledgement}

Grant support: OPVaI ITMS2014+: 313012Q751

\section{References}

ABBASIHORMOZI S, KOUHKAN A, ALIZADEH AR, SHAHVERDI AH, NASR-ESFAHANI MH, SADIGHI GILANI MA, SALMAN YAZDI R, MATINIBEHZAD A, ZOLFAGHARI Z: Association of vitamin D status with semen quality and reproductive hormones in Iranian subfertile men. Andrology 5: 113-118, 2017. https://doi.org/10.1111/andr.12280

ALZOUBI A, MAHDI H, AL BASHIR S, HALALSHEH O, AL EBBINI M, ALZARIR M, AL-AHMAR K, ALFAQIH M, AL-HADIDI AH: Normalization of serum vitamin D improves semen motility parameters in patients with idiopathic male infertility. Acta Endocrinol (Buchar) 13: 180-187, 2017. https://doi.org/10.4183/aeb.2017.180

ANIC GM, ALBANES D, ROHRMANN S, KANAREK N, NELSON WG, BRADWIN G, RIFAI N, MCGLYNN KA, PLATZ EA, MONDUL AM: Association between serum 25-hydroxyvitamin D and serum sex steroid hormones among men in NHANES. Clin Endocrinol (Oxf) 85: 258-266, 2016. https://doi.org/10.1111/cen.13062

BOUILLON R, MARCOCCI C, CARMELIET G, BIKLE D, WHITE JH, DAWSON-HUGHES B, LIPS P, MUNNS CF, LAZARETTI-CASTRO M, GIUSTINA A, BILEZIKIAN J: Skeletal and extraskeletal actions of vitamin D: current evidence and oustanding questions. Enocr Rev 4: 1109-1151, 2019. https://doi.org/10.1210/er.2018$\underline{00126}$

BLOMBERG JENSEN M, JØRGENSEN A, NIELSEN JE, BJERRUM PJ, SKALKAM M, PETERSEN JH, EGEBERG DL, BANGSBØLL S, ANDERSEN AN, SKAKKEBAEK NE, JUUL A, RAJPERT-DE MEYTS E, DISSING S, LEFFERS H, JØRGENSEN N: Expression of the vitamin D metabolizing enzyme CYP24A1 at the annulus of human spermatozoa may serve as a novel marker of semen quality. Int J Androl 35: 499-510, 2012. https://doi.org/10.1111/j.1365-2605.2012.01256.x 
BLOMBERG JENSEN M, BJERRUM PJ, JESSEN TE, NIELSEN JE, JOENSEN UN, OLESEN IA, PETERSEN JH, JUUL A, DISSING S, JØRGENSEN N: Vitamin D is positively associated with sperm motility and increases intracellular calcium in human spermatozoa. Hum Reprod 26: 1307-1317, 2011. https://doi.org/10.1093/humrep/der059

BLOMBERG JENSEN M, GERNER LAWAETZ J, ANDERSSON AM, PETERSEN JH, NORDKAP L, BANG AK, EKBOM P, JOENSEN UN, PRÆTORIUS L, LUNDSTRØM P, BOUJIDA VH, LANSKE B, JUUL A, JØRGENSEN N: Vitamin D deficiency and low ionized calcium are linked with semen quality and sex steroid levels in infertile men. Hum Reprod 31: 1875-1885, 2016. https://doi.org/10.1093/humrep/dew152

CICCONE IM, COSTA EM, PARIZ JR, TEIXEIRA TA, DREVET JR, GHARAGOZLOO P, AITKEN RJ, HALLAK $\mathrm{J}$ : Serum vitamin D content is associated with semen parameters and serum testosterone levels in men. Asian $\mathrm{J}$ Androl 23: 52-58, 2021. https://doi.org/10.4103/aja.aja_ 920

CITO G, COCCI A, MiCElli E, GABUTti A, RUSSO GI, COCCIA ME, FRANCO G, SERNI S, CARINI M, NATALI A: Vitamin D and male fertility: an updated review. World J Mens Health 38: 164-177, 2020. https://doi.org/10.5534/wjmh.190057

GLAZER CH, BONDE JP, EISENBERG ML, GIWERCMAN A, HÆRVIG KK, RIMBORG S, VASSARD D, PINBORG A, SCHMIDT L, BRÄUNER EV: Male infertility and risk of nonmalignant chronic diseases: a systematic review of the epidemiological evidence. Semin Reprod Med 35: 282, 2017. https://doi.org/10.1055/s-0037-1603568

HAMMOUD AO, MEIKLE AW, PETERSON CM, STANFORD J, GIBSON M, CARRELL DT: Association of 25-hydroxy-vitamin D levels with semen and hormonal parameters. Asian J Androl 6: 855, 2012. https://doi.org/10.1038/aja.2012.77

BØLLEHUUS HANSEN L, REHFELD A, DE NEERGAARD R, NIELSEN JE, IVERSEN LH, BOISEN IM, MORTENSEN LJ, LANSKE B, ALMSTRUP K, CARLSEN E, BERG AH, JØRGENSEN N, ANDERSEN AN, JUUL A, BLOMBERG JENSEN M: Selection of high-quality spermatozoa may be promoted by activated vitamin D in the woman. J Clin Endocrinol Metab 102: 950-961, 2017.

HANSON, B.M., EISENBERG, M.L., Hotaling, J.M. et al.: Male infertility: a biomarker of individual and familial cancer risk. Fertil Steril 109: 6-19, 2018. https://doi.org/10.1016/i.fertnstert.2017.11.005

JACKULIAK P, PAYER J: Significance of vitamin D in diabetology Via practica 9: 201-204, 2012.

JØRGENSEN N, VIERULA M, JACOBSEN R, PUKKALA E, PERHEENTUPA A, VIRTANEN HE, SKAKKEBAEK NE, TOPPARI J: Recent adverse trends in semen quality and testis cancer incidence among Finnish men. Int J Androl 34: e37-e48, 2011. https://doi.org/10.1111/j.1365-2605.2010.01133.X

JUERAITETIBAIKE K, DING Z, WANG DD, PENG LP, JING J, CHEN L, GE X, QIU XH, YAO B: The effect of vitamin D on sperm motility and the underlying mechanism. Asian J Androl 21: 400-407, 2019. https://doi.org/10.4103/aja.aja_105_18

KASMAN AM, LI S, LUKE B, SUTCLIFFE AG, PACEY AA, EISENBERG ML: Male infertility and future cardiometabolic health: does the association vary by sociodemographic factors? Urology 133: 121-128, 2019. https://doi.org/10.1016/j.urology.2019.06.041

KUMARI S, SINGH K, KUMARI S, NISHAT H, TIWARY B: Association of vitamin D and reproductive hormones with semen parameters in infertile men. Cureus 13: e14511, 2021. https://doi.org/10.7759/cureus.14511

MACOVA L, BICIKOVA M, HAMPL R: Impaired vitamin D sensitivity. Physiol Res 67 (Suppl 3): S391-S400, 2018. https://doi.org/10.33549/physiolres.934006

PLUDOWSKI P, HOLICK MF, PILZ S, WAGNER CL, HOLLIS BW, GRANT WB, SHOENFELD Y, LERCHBAUM E, LLEWELLYN DJ, KIENREICH K, SONI M: Vitamin D effects on musculoskeletal health, immunity, autoimmunity, cardiovascular disease, cancer, fertility, pregnancy, dementia and mortality-a review of recent evidence. Autoimmun Rev12: 976-989, 2013. https://doi.org/10.1016/j.autrev.2013.02.004

RAMLAU-HANSEN CH, MOELLER UK, BONDE JP, OLSEN J, THULSTRUP AM: Are serum levels of vitamin D associated with semen quality? Results from a cross-sectional study in young healthy men. Fertil Steril 95: 1000-1004, 2011. https://doi.org/10.1016/j.fertnstert.2010.11.002 
RASTRELLI G, LOTTI F, REISMAN Y, SFORZA A, MAGGI M, CORONA G: Metabolically healthy and unhealthy obesity in erectile dysfunction and male infertility. Expert Rev Endocrinol Metab 14: 321, 2019. https://doi.org/10.1080/17446651.2019.1657827

REHMAN R, LALANI S, BAIG M, NIZAMI I, RANA Z, GAZZAZ ZJ: Association between vitamin D, reproductive hormones and sperm parameters in infertile male subjects. Front Endocrinol (Lausanne) 9: 607, 2018. https://doi.org/10.3389/fendo.2018.00607

ROSEN CJ, ABRAMS SA, ALOIA JF, BRANNON PM, CLINTON SK, DURAZO-ARVIZU RA, GALLAGHER JC, GALLO RL, JONES G, KOVACS CS, MANSON JE, MAYNE ST, ROSS AC, SHAPSES SA, TAYLOR CL: IOM commitee members respond to Endocrine Society vitamin D guideline. J Clin Endocrinol Metab 97: 1146-1152, 2012. https://doi.org/10.1210/jc.2011-2218

SALONIA A, BETTOCHI C, CARVALHO J, CORONA G, JONES TH, KADIOGLU A, MARTINEZSALAMANCA AI, MINHAS S: EAU Sexual and Reproductive Health Guidelines, part 9. Male Infertil, Update 2020.

WEHR E, PILZ S, BOEHM BO, MÄRZ W, OBERMAYER-PIETSCH B: Association of vitamin D status with serum androgen levels in men. Clin Endocrinol (Oxf) 73: 243-248, 2010. https://doi.org/10.1111/j.13652265.2009.03777.x

WULANINGSIH W, VAN HEMELRIJCK M, MICHAELSSON K, KANAREK N, NELSON WG, IX JH, PLATZ EA, ROHRMANN S: Association of serum inorganic phosphate with sex steroid hormones and vitamin D in a nationally representative sample of men. Andrology 2: 967-976, 2014. https://doi.org/10.1111/andr.285 